\title{
Wounding Ideals: Israel Epstein's Life Saga in Communist China
}

\author{
Mengxi Sun \\ Cornell University, New York, USA
}

\begin{abstract}
Despite of all its enigma and revealingness, Israel Epstein's (1915-2005) life in communist China remains a vacuum in English-language scholarship on the history of the People's Republic of China. This paper intends to fill this vacuum. It seeks to rediscover Epstein's communist experience, with particular focus on his fervent activism in and unapologetic defense of the Cultural Revolution. Through analyzing his experience, this paper exposes the essential allurement of Chinese communism encapsulated in the ideals of revolutionary regeneration and revolutionary virtues. Beyond Epstein's communist experience, this paper calls for a deeper and broader pondering on the analogy between communism and religion. Such an illuminating analogy should inspire more intellectual efforts than critical expositions of formalistic vainglory or personality cult.
\end{abstract}

Keywords: Israel Epstein, Chinese Communist Party, Pro-communism foreigners, cultural revolution

\section{Introduction}

Who is Chinese Communist Party's (CCP) favorite foreign-born comrade? Not Agnes Smedley (1892-1950), not Edgar Snow (1905-1972), not Anna Louise Strong (1885-1970), or any other Western journalistsor intellectuals. For one thing, they never joined the party; for another, they did not spend the bulk of their life in communist China. Israel Epstein (1915-2005) did both. A veteran journalist, author, and propagandist, he took Chinese nationality in 1957, became a CCP member in 1964, and spent 82 out of 90 years of his life time in China ("Israel Epstein", 2005). Mao Zedong (1893-1976)—the "great helmsman"-regularly consulted him about "new China's" nation branding ("Israel Epstein", 2005). Deng Xiaoping (1904-1997) — the "chief architect of reform and opening-up"-attended his retirement reception in 1985 (Douglas, 2005). His birthday parties were honored by the visits of Presidents Jiang Zemin and Hu Jintao as well as Premiers Zhu Rongji and Wen Jiabao. ${ }^{1}$ Ever since its foundingin 1949, the Chinese People's Political Consultative Conference (CPPCC) has seldom, if ever, opened to foreign-born individuals. But, he was "elected" to the CPPCC Standing Committee in 1984 (WU, 2013).

The ultimate reward for his loyalty is even more spectacular in form and consoling for spirit. After the end

\footnotetext{
Mengxi Sun, Masters Student, Department of Asian Studies, Cornell University.

${ }^{1}$ See “President Jiang Zemin Congratulated Israel Epstein on His 80th Birthday in 1995” (“1995 年江泽民祝贺爱泼斯坦 80 大 寿”), China.com, 17 April. 2005, http://www.china.com.cn/chinese/zhuanti/at/840297.htm, Accessed 30 Dec. 2016; “President Hu Jintao Visits Israel Epstein” (“胡锦涛亲切看望爱泼斯坦”) People.cn, 17 April. 2005, http://politics.people.com.cn/GB/1024/3327158.html. Accessed 30 Dec. 2016; “Zhu Rongji meets Israel Epstein” (“朱镕基接见 爱泼斯坦”) China.com, 17 April. 2005, http://www.china.com.cn/chinese/zhuanti/at/840306.htm. Accessed 30 Dec. 2016; “Premier Wen Jiabao visits Senior Foreign Expert Israel Epstein” (“国务院总理温家宝看望外国老专家爱泼斯坦”) People.cn, 20 April, 2003, http://people.com.cn/GB/shizheng16/20030420/976253.html. Accessed 30 Dec. 2016.
} 
of his days, he was buried at the Babaoshan Cemetery for Revolutionaries - the sanctuary for communist martyrs and luminaries. His funeral, held on June 3, 2005, was honored by the attendance of President $\mathrm{Hu}$ Jintao, Premier Wen Jiabao, and several Politburo Standing Committee members (Epstein's Body Cremated in Beijing, 2005). Four years after his passing away, in a government-run public diplomacy campaign commemorating the 60th birthday of the People's Republic of China (PRC), he was "elected" as one of China's ten most beloved "international friends", standing on an equal footing with Maha Chakri Sirindhorn, Princess of Thailand, and Marquis Juan Antonio Samaranch (1920-2010), the seventh President of the International Olympic Committee. (China Awards Top Ten International Friends, 2009). Few of CCP's foreign aides lived long enough and remained committed enough to procure such magnanimous reward.

Indeed, prestige is the central motif of his twilight years. But, just as the party's reign was nothing short of tumults and contradictions, Epstein's unflinching loyalty to the regime is a motley of idealism, bewilderment, yearning, fear, and quasi-religious piety. Although influential English-language media, such as The New York Times (Douglas, 2005) and The Telegraph (Israel Epstein, 2005) mentioned his passing away on May 26, 2005, his communist experience remains a vacuum in the English-language research of modern China. This paper intends to anatomize his life saga, with a particular focus on his high-profile activism in the Cultural Revolution and unapologetic defense for its catastrophic consequence. It will answer two critical questions: What allured him to play an active role in the inglorious havoc? And, what underlay his disgraced activism? By pondering these two questions, we can not only see through his mixed political psyche but also gain a deep understanding of the paradoxical nature of CCP rule.

\section{Predestined Conversion}

Born in Warsaw in 1915 to a Jewish family, Epstein grew up in Harbin and Tianjin, China (Epstein, 2005, p. 5). His father and aunt were active members of Bund, or Jewish Labor Alliance, originally a section of the Russian Social-Democratic Labor Party (Epstein, 2005, p. 13). Such a family background predisposed him to socialism and communism.

At an age of 19, he, with a dozen young expatriates, began reading socialist classics, communist doctrines, and progressive contemporary publications. Every week, they gathered to discuss Marxism and current world affairs. Such a radical political bent cost him his first job - a reporter position at the English-language Peking and Tientsin Times. After catching him with an American communist publication sticking out of his pocket, the business manager immediately fired him.

Sooner, the Second Sino-Japanese War (1937-1945) broke out at full scale. Epstein, after doing freelance writing under pen-name for oversea publications, was employed by the United Press to cover the war (Epstein, 2005, p. 67). In September 1938, he met Soong Ching-ling (1893-1981) in Guangzhou. Having seen Chinese people's heroic resistance against Japanese invasion, he decided to join her China Defense League. In the next two years, he had worked for the organization in Hong Kong (Epstein, 2005, p. 108).

He fled to Chongqing, after Hong Kong fell into Japan's hand. While staying in Chongqing from 1940 to 1944, he, just as many Western journalists and foreign-service officers, became increasingly disillusioned with the Kuomintang (KMT) government for its authoritarian bent, corruption, incompetence, and pettiness. The CCP regime and the "revolutionary base areas" under its reign become increasingly appealing and promising in their eyes, although few, if any, of them had in-person encounters with the enigmatic "red power". After an unfriendly to-and-fro with KMT authorities who labored assiduously to demonize communists aspoppy 
planters, cowards, and oppressors, nine Chinese journalists and six foreign journalists, including Israel Epstein and Harrison Forman (1904-1978) - author of the influential Report from Red China, were allowed to enter the Shann-Gan-Ning Border Region (Shewmaker, 1971, p. 165).

Officially designated as the "press party to the Northwest", the group spent six months in Yan'an, visiting villages and factories and meeting with party leaders, including the "great helmsman" and Premier Zhou Enlai (1898-1976). Epstein enjoyed many long conversations with Mao (Douglas, 2005), which, as he later recalled, "changed his life". Moreover, he was galvanized by what he witnessed with his own eyes - the ongoing transformation of local society, and above all, of the vast peasant population. He had good reasons to be so. Through land reform, the CCP managed to elevate peasants out of exploitation, and then unleashed their energy and potential in the "Production Movement" and "Cooperation Movement". It weakened the landlord class with sheer determination and force, and extended political empowerment to peasants. It forged a "new citizenry" through ideologically loaded cultural and educational campaigns, instilling incadres and peasants an upbeat spirit of patriotism and self-reliance (Selden, 1972, pp. 210-212).

At that time, the CCP regime, though unabashedly totalistic, was indeed more efficient, egalitarian, and clean than the KMT government. No wonder that foreign journalists in the "press party" were willing to "believe in what they were shown" in calculatingly arranged "political tourism"; they even submitted their reports to the regime's Ministry of Information for censorship (Brady, 2003, p. 59). Their finalized account on Yan'an, of course, was mostly favorable toward the regime, evincing the futility of KMT's self-defeating press policies, which, as pointed out by the U.S. ambassador Clarence Gauss (1887-1960), was an exhibition of "near-stupidity" and worked to the advantage of the CCP (Shewmaker, 1971). For example, Forman saw "representative democracy" in CCP's mass-line approach toward political mobilization; even Gunther Stein (1900-1961), a KMT agent for the Christian Science Monitor, concluded that the party had endorsed "genuine local self-government" (Shewmaker, 1971, p. 166).

Epstein's appreciation on the CCP regime was far broader than its political governance. He was stunned by CCP's capacity in reinventing not only political life but also economic, ideological, cultural, and educational fabrics of local society. He was convinced that the CCP, with its Marxist beliefs and executive competence, was the only hope for an oppressed and impoverished China. Such a conviction was at the root of his oversea activism and wholehearted dedication to Chinese communism. While staying in the U.S. from 1945 to 1951 , Epstein and his wife Elsie Fairfax-Cholmeley (1905-1984) had worked for the Committee for a Democratic Far Eastern Policy to advocate the US government to recognize and establish friendship with the CCP (Epstein, 2005, p. 233). He left the US in March 1951, after immigration authorities, alerted by his pro-communism activism, summoned him to a hearing hinting on possible deportation (Epstein, 2005, p. 236-237). Upon Soong Ching-ling's invitation, he returned to China in the same year to serve as the editor of China Reconstructs which was later renamed China Today (Epstein, 2005, p. 237). For the next three decades until retirement, he had worked for the magazine and engaged in state-sponsored foreign-language publicity campaigns, toiling at the forefront of communist China 's propaganda offensive.

\section{Imposed Privilege and Quasi-segregation}

One may automatically assume that CCP's foreign sympathizers, such as Epstein, would find amiable inclusion in the PRC whose Marxist faith, egalitarian spirit, and anti-imperial stance resonated so strongly with their left-liberalist bent and internationalist aspiration. In logic, they should. From Marx (1818-1883) and 
Engels (1820-1895) to Lenin (1870-1924) and Bukharin (1888-1938), communist struggles had always been branded as necessarily universalistic in nature and global in scale. Since capitalist exploitation, imperialist expansion, and colonial oppression knew no border, proletarian emancipation must transcend narrow-minded nationalist concerns and usher in full-scale independence for all suffered peoples. "The Internationale", calling on the deprived everywhere to "group together", had been chanted by socialists and communists everywhere for more than a half century. For decades, the Comintern, though dominated by the Soviet Union in reality, had popularized an arresting ideal of "abolish[ing] frontiers between states, transform[ing] the whole world into a community" of freedom, brotherhood, and common good (Vatlin \& Smith, 2015, p. 189), not to mention the charisma of the good "Yan' an years" when "international friends", equipped with much needed medical, journalistic, and language expertise, were heartily welcomed by the party.

But, once the perennial underdog came into power, it did not reward Epstein and other pro-communism foreigners with trust - the bedrock of true friendship. Instead, most resident foreigners were assigned Chinese accompanies who kept track of their daily activities and opinions on various issues (Brady, 2003, p. 102). Chinese personnel who had contact with foreigners were ordered to follow "foreign affairs" regulations on how to interact with them (Brady, 2003, p. 93). Moreover, pro-CCP foreigners were discouraged from mingling with "bourgeoisie" foreigners from diplomatic communities whose hearts and minds did not resonate with communist causes (Brady, 2003, p. 102). Even Rewi Alley (1897-1987), later to become one of PRC's ten most beloved "international friends", had been shut out of the new society for a while, due to his previous connection with foreign aid organizations (Brady, 2003, p. 99).

How to explain CCP's chilling restrictive measures against its foreign-born followers? The party's bone-deep feeling of insecurity, evidenced by penetrating policing organs and unremitting purging campaigns, was the primary reason. External threats from the defeated KMT regime in Taiwan and its powerful ally - the US - amounted to the other. The party's anxiety over betrayal was later to become "the border pass that led from 'new democracy' to Cultural Revolution" (Dutton, 2005, p. 132). Since the party still needed the knowledge, skills, and symbolic value of their "international friends", it was willing to provide them with wages ten times that of ordinary Chinese workers and three to four times that of Chines professors, not to mention comfortable housing and ample daily necessities that most Chinese could never dream of (Brady, 2003, p. 91). But, would any foreigner who came to communist China with genuine hope and enthusiasm in its cause be content with quasi-segregation?

By all means, no. The grandiose Friendship Hotel was jibed as "golden ghetto" by foreigners who were pressured to live here. The English communist journalist Eric Gordon - a reluctant dweller-complained that that his Chinese comrades, instead of sharing revolutionary passion with foreigners, had deliberately isolated them from political discussions and wooed them with perfunctory "excursions to the Great Wall, Summer Palace, Ming Tombs, dances, films, and Beijing opera visits" - an upgraded version of Yan'an-style "political tourism". Such kind of "mercenary relationship" is an anathema of their communist-internationalist aspiration (Brady, 2003, p. 132).

One would assume that Epstein never experienced quasi-segregation and perfunctory "political tourism". After all, nowhere in his autobiography and media interviews did he vent similar discontent. But, is there any reason that would compel the party sparing him alone from such apathetic treatments? Hardly any. The vacuum in his autobiographic account is a conscious avoidance of inconvenient facts that are at odds with CCP's bidding for international friendship. His scrupulous self-censorship revealed what the party liked most about 
him and what earned him esteem in post-Mao China — steadfast conformity to party line.

Didn't he want to endeavor for national causes with Chinese "class brothers"? Didn't he want to participate in Chinese political life? By all means, he yearned for inclusion, which was evidence by the spiritual joy he experienced in physical labor - an important component of socialist collective production movement in rural areas:

Later we joined other work groups in transplanting rice, harvesting wheat, afforesting bare hills, or digging a canal. All this made us, as nothing else could, forever a part of this land, shaped, tilled, and watered by the soil of so many generations, and now in a state of active rebirth. Whenever we saw new watercourses, roads, or tree-belts, we felt that we, too, had helped create them. Such a feeling is hard to describe by any who have not worked truly mutually, not for monetary wealth, but for a common aim. (Brady, 2003, p. 255)

Sadly, "we" in these sentimental lines singularly referred to the small group of foreign translators and language polishers; the physical labor program, two weeks in length, was just another "political tourism" tailor-made for foreigners who yearned for belongingness and togetherness. For them, the Cultural Revolution was a godsend.

\section{The Havoc}

The "great helmsman" once again captured public passion and unconditional adherence, when he declared war against the "Capitalist path" undertaken by top party authorities as well as the "bourgeois and feudalist ideologies" and pandemic cultural decay plagued the intelligentsia and the party's elite circle. This war must be won, since, as he perceived, "new China's" socialist ethos and revolutionary impulse were now dying. What he hid from low-level cadres and the people was his brutal power struggle with Liu Shaoqing and many high-level officials who, being increasingly aware of the absurdity and disastrous consequences of his unrealistic economic policies, started doubting his judgment and challenging his authority, openly and tacitly. Published in November 1965 under Mao Zedong's (1893-1976) commission, Yao Wenyuan's (1931-2005) critique on Wu Han's "HaiRui Dismissed from Office" set in motion a string of political purging and ignited the "Great Proletarian Cultural Revolution" (Meisner, 1999, pp. 313-315).

In the humanities and social science literature, revolution is defined as "a major, sudden, and hence typically violent alteration in government and in related associations and structures" ("Revolution", 2015). The alteration of the old, ipso facto, entails a radical promise of everything anew. Such definition leaves out the connotation of irresistibility embedded in the Latin root of this term which, in its archaic scientific usage, designated the recurring, lawfully cyclical movement of stars (Arendt, 2006, p. 32). The Cultural Revolution has nothing to do with lawfulness. But, it is absolutely irresistible. Epstein was thrilled, bewildered, and possessed. In a letter to Maud Russell (1893-1989), the editor of the Far East Reporter and executive director of the Committee for a Democratic Far Eastern Policy, he exalted:

We are indeed living through tremendous days, weeks, and months that do indeed "shake the world"-rejuvenating, revivifying, scraping all the barnacles off the mind and scraping off those who have themselves become barnacles on the cause. $^{2}$

\footnotetext{
${ }^{2}$ Anne-Marie Brady, Making the Foreign Serve China: Managing Foreigners in the People's Republic, p. 156. The original correspondence and other documents that Maud Russell collected have been preserved at the New York Public Library.
} 
Epstein's mindset was well attuned to the hectic tempo of the revolutionary time zone where an all-encompassing iconoclasm decked each nonetheless ordinary day with an aura of historical significance, where collective self-aggrandizement was legitimized by a seemingly righteous cause. What could be more righteous than reversing the decay of party and the country? In indeed, Mao's anti-revisionism rhetoric was morally irrefutable.

He and other pro-communism foreigners did not stop at extolling. The revolutionary hurricane shook all established institutions, including the restriction and surveillance measures that had prohibited them from participating in meaningful political activities. In the revolution time zone, inaction signaled disloyalty; radical behaviors were the norm. They acted swiftly to rid the decade-long quasi-segregation, and they succeeded.

On August 29, 1966, four American foreign experts wrote a "big-character poster" entitled: Why is it that foreigners working here in the heart of the world revolution are being pushed down the revisionist road?, rendering a selfless cautioning that foreigners' privilege in wage, housing, and daily subsistence was at odds with the ideal of a classless society that motivated them to stand with Chinese Communism at the first place (Chou, 2009, pp. 341-3). The group consisted of Joan Hinton (1921-2010) and Sid Engst (1919-2003), Bertha Sneck, and Ann Tompkins. Much to their delight, Mao rewarded their uprightness by approving their demand on being "treated exactly the same as Chinese" (Epstein, 2005, p. 289). The promise of exact sameness was more rhetorical than factual. The party did not change the income and living standards applied to foreigners, so they still had to "bear with" privileged treatments. But, they were allowed to participate in the current revolutionary movement with Chinese; mass meetings and political study sessions were opened to them.

Epstein was completely thrilled. Being a rank-and-file participant of the movement was below his aspiration. Being "the first to respond positively and publicly" to the party's gesture of political inclusion, heset up a "red guard-type group" named "Bethune-Yan'an Rebel Regiment of Mao Zedong thought" in January 1967 (Epstein, 2005, p. 289). He and dozens of foreigners clamored for becoming Mao's "red guards".

"Bethune" (1890-1939) embodied the internationalist ideals of communism, which was cemented by Mao's ardent praise as early as in 1939:

What kind of spirit is this that makes a foreigner selflessly adopt the cause of the Chinese people's liberation as his own? It is the spirit of internationalism, the spirit of communism, from which every Chinese communists must learn. (MAO, 1996, p. 28)

Now that Mao was concerned with revitalizing the spirit of self-effacing dedication, the example of Bethune had been widely celebrated during the Cultural Revolution (Brady, 2003, p. 55). Having yearned for belongingness and togetherness for more than a decade, Epstein and other foreigners would not miss this opportunity. The symbolical value of Bethune was a strategic asset for internationalists like them. "Yan'an", as a locality, a temporality, and a memory, conjured up the liveliest chapter of proletariat struggles led by the CCP. "Rebel", extracted from Mao's famous remark-“the right to rebel", was the sine qua non of rejuvenation, revival, and re-cleansing of the collective revolutionary mind-body. "Mao Zedong thought" was the ultimate exoneration for any outrageous undertaking in the revolutionary time zone.

The "Bethune-Yan'an Rebel Regiment" was a high-profile phenomenon in 1967 and 1968. Numerous Chinese "rebel groups" who blustered to export the revolution abroad invited its members to attend meetings, in order to assure Chinese participants that "their cause had acquired worldwide significance", that they would "liberate the whole universe" (Brady, 2003, p. 149) in the near future. Epstein, as one of the regiment's chief 
leaders, diligently attended these meetings and presented more than 20 speeches in education institutions in the capital area. He did not mind leaders of Chinese "rebel groups" borrowing the symbolic value of his foreign face. Rather, he toiled to meet that demand. Sidney Rittenberg (born in 1921), the unofficial leader of the group and the most provocative foreign propagandist in the 1960s, impressed his workmates at the National Radio with a candid confession of his "bourgeoisie elitism" (Brady, 2003, p. 147) and enchanted legions of radical students with his powerful political speeches (Brady, 2003, p. 155). Having lived and worked in quasi-segregation for more than a decade, pro-communism foreigners, for the first time, were given the opportunity to play a commanding role on "new China's" political stage-a spectacular, tempestuous revolutionary theatre of boundless possibilities, and they seized the moment.

Quasi-segregation not only caused and intensified the yearning for acceptance but also spawned fear. Fear of persecution was another emotional motive that drove Epstein to move in step with the Cultural Revolution. In his autobiography, he admitted that "not to be left behind, dejected and rejected" was one consideration that drove him to stand out among pro-communism foreigners in the initial stage of the havoc (Brady, 2003, p. 155). Logically, we have to ask: "[T]o be left behind, dejected and rejected" by whom?

The party, having reined over the mass and charted the course of revolution, possessed both tangible power and ideological righteousness to dislodge individuals of dubious commitment. The mass, having been molded into communist "new citizenry" by unceasing ideological propagandas at schools and workplaces, enthusiastically followed the "great helmsman's" decrees, whatever they were, whenever they were issued. Pro-communism foreigners, having been shut "outside the people" by imposed privilege, were living in a prolonged peril of being "left behind, dejected and rejected" by the party and the people. Even more menacing, the Maoist logic of "democratic dictatorship" mandated that those who were "being outside the people" were presumably non-people (Lifton, 1989, p. 433). Everyone who was physically in China at that time knew too well-known people — landlords, capitalists, and bourgeoisie intellectuals — had been treated. The peril was real, so was the fear that kept haunting Epstein and many other foreigners. In this light, Epstein's heroic vanguard posture was propelled by a not so heroic emotion duplex-yearning for acceptance and fear of banishment.

\section{Defense the Indefensible}

The CCP did not bother to sooth his emotion; human emotions of any sort, are seldom, if ever, a priority in CCP's ironclad decision-making process. Even worse, his forthright, diligent activism invited suspicion from top authorities, instead of praise. As factional in fightings within the party's inner circle grew ferocious, foreigners in the Bethune-Yan'an group started conducting power struggles along the lines of "rebels" and "loyalists", mimicking the Chinese situation (Brady, 2003, p. 160). In a zero-sum power game, someone must be on the losing side. Epstein and his wife Elsie, being accused of engaging in espionage and plotting against Zhou Enlai, were unmitigated losers (Epstein, 2005, p. 299). For all we know about the legal system of communist China and the political ambience of the Cultural Revolution, it is neither practical nor sensible for them to plead not guilty. For the next five years, they were imprisoned first in an army camp near the Summer Palace and then in the infamous Qincheng Prison (Epstein, 2005, p. 306). Rittenbergtoo was incriminated as a spy and thrown into jail (Bennett \& Rittenberg, 1993, p. 389). The Bethune-Yan'an group collapsed. The political inclusion extended to "international friends" came into a halt. From January 1968, foreigners were prohibited to participate in the Cultural Revolution and form their own political study groups (Epstein, 2005, p. 299). 
One would assume that Epstein was embittered by the five-year imprisonment—a merciless thwack to his revolutionary candor. No, he wasn't. He told The New York Times that, the imprisonment "had helped improve him by shrinking his ego" (Douglas, 2005). In his autobiography, he pitched an audacious defense for the purely man-made, practically indefensible catastrophe. In his view, "the original thrust of the Cultural Revolution...contained, and even enhanced, some good qualities long taught by the Chinese Communist Party". These "good qualities" are:

The absence of greed; faith in an ever-better future; the spirit of service to the people; the prevalence of mutual aid, rarity of theft, and readiness of all ranks of society, and particularly of the youth, to volunteer despite fatigue and peril. (Epstein, 2005, p. 295)

The five-year imprisonment he and his wife had suffered added to this defense a hue of self-sacrificial devotedness. Prevailing and ennobling, the communist moral sentiment had hovered in his mind for more than a decade, which partly explained why he went on defending the Cultural Revolution. It stemmed from his participation in the "Three-anti" and "Five-anti" Campaigns (1951-52) triggered by the incrimination of Liu Qingshan (1916-1952) and Zhang Zishan (1914-1952) who, with notable military and political records, swiftly weaved a network of corruption and embezzlement after the birth of the "new China". Freshly joined the CCP camp with hope and aspiration, Epstein was shocked by "the unveiling of erosion, in the revolutionary structure itself, of the post-liberation spirit of simplicity and integrity” (Epstein, 2005, pp. 255-256).

Growing up in Tianjin as a teenager, he knew too well the milieu of rottenness in the "old China". Having worked as a journalist for more than two decades, he was keenly aware of the rampant corruption among KMT officials. Such unsettling firsthand knowledge made him genuinely cherish the stark contrast between the spartan, upbeat "new China" and the decayed, moribund "old China". But, early experience alone cannot explain why he went so far as to moralize the bloodstained Cultural Revolution. Beneath his improbable defense is a stubborn adhesion to ideological totalism indoctrinated by the totalistic CCP regime. It dichotomized the world into the pure and the impure, into the absolutely good and the absolutely evil; it perpetuated an extreme sense of shame and guilt in people's minds (Lifton, 1989, p. 423). The party, in meanwhile, acted as the only legitimate force to conduct an all-out, unrelenting war upon the impure and the evil. To annihilate them, any cost is justified; no sacrifice is unbearable; all tragedies are deemed minor dissonances in a preordained triumphant symphony. True, Epstein and many other pro-CCP foreigners were far more faithful to communism than Soviet ruling elites whose "lip service to the creation of the 'new man' was all too easily combined with an acceptance of privilege and conservative defense of a status quo" (Brown, 2009, p. 134). But, the plain truth is, a morally luminous, materially egalitarian, and all-perfect society not only never exists in human history but is simply alien to the human condition.

\section{The Aftermath}

Epstein and his wife Elsie were released from incarceration in January 1973 (Brown, 2009, p. 319). While attending a meeting held at the Great Hall of the People on March 8 1973, Zhou Enlaiapologized to foreigners who were mentally and physically maltreated during interrogation and incarceration. He denounced exclusivism, racism, and chauvinism inflicted on foreigners and vowed to uphold the principle of internationalism (Brady, 2003, p. 184). Was this a genuine confession or a manipulative tactic to garner "international friends" support for the party's new foreign policy directions? It is not easy to pin down a 
definitive answer. Again, nowhere in his autobiography and media interviews did Epstein mention this well-staged event. But, he forgave the party right away.

Unlike Rittenberg who was embittered by the CCP's dictatorial nature and boarded on a plane for America with his family in 1980 (Bennett \& Rittenberg, 1993, p. 446), Epstein remained staunchly loyal to the party and stayed in China for the rest of his life. Unlike Rittenberg who rejected the seat on the CPPCC that the party granted to him right after the Cultural Revolution (Bennett \& Rittenberg, 1993, p. 446), Epstein accepted a similar offer in 1983 - an offer of acceptance and inclusion that he had longed for nearly three decades. Unlike Rittenberg who proclaimed the extinction of authentic communists worldwide in an interview with the BBC (Bristow, 2011), Epstein, convinced by the scientific validity of Marx's historical materialism, had unwavering faith in the eventual advent of communism as the consummation of human history. "At the end of the day, I remain a Marxist...for Marxism is not a prophecy but a method of analysis", he professed on the last page of his autobiography (Epstein, 2005, p. 342).

Commenting on Epstein's life saga, the London-based The Observer opined, "perhapsthe most loyal Communists in the country today are foreigners, veteran fellow travelers from a vanished era of idealism". Epstein's beliefs and actions epitomized communist-internationalist idealism. He was too moral, too loyal, and too devoted to the extent that questioning the party's conspicuous record of terror is utterly unthinkable. Nor did he ever challenge the widening incongruity between the party's unremitting preaching on socialist virtues and its subservient worship of economism. He subscribed to "socialism with Chinese characteristics" with ease, embracing the evasive, cumbersome party line that concrete steps toward realizing communism "vary with the situation and degree of development of each country and depend on the recognition of the people of their possibility and necessity" (Epstein, 2005, p. 328). Ingrained obedience aside, his pious belief in the eventual advent of communism smoothed such mental shift - China, and in a broader sense, the world WILL become a communist utopia FOR SURE, although "there is no timetable". This is a standard reiteration of standard party rhetoric. While party theorists assumed that they worked out an ingenious reconciliation between unabashed economic pragmatism and illusory ideological goals, the plain fact is that believers from the "vanished era of idealism" have withered away one after another, subsequent generations simply don't bother with belief or non-belief in an "age of ambition".

\section{Conclusion and Reflection}

Epstein's inner and outer experience in Communist China is a perfect mirror of the turbulence, contradictions, and illusions characteristic of CCP rule. The vision of revolutionary regeneration was irresistible, for it promised an existentially ennobling, larger-than-life experience. The ideal of revolutionary virtues was no less alluring, as their regenerative power was attested by the unmistakable contrast between the "new China" and the old. Epstein cherished them. Millions of foreign idealists and radical Chinese youth cherished them. Perhaps the party and Mao himself too genuinely cherished them. But, beneath their luminous veneers, in the high-sounding name of revolution, coercion and violence shattered humanity. Ironically, coercion and violence did not preserve Maoist revolutionary impulse for long. Today, when the party defends its legitimacy, its strongest card is the "new China's" material wealth accumulated in a typical capitalist way. Indeed, China was regenerated. But, it was regenerated by Deng Xiaoping's (1904-1997) hyper-driven economic pragmatism, not by Maoist ideologies or virtues of any sort. 
Ideals aside, at the psychological level, the longing for acceptance and fear of banishment are rooted in human beings' innate desire for self-preservation. The Cultural Revolution instigated these twin human instincts on a pan-societal scale, and Epstein was not immune from this all-encompassing torrent. $\mathrm{He}$, as a foreigner in a land of fervor and rage, must feel it more keenly than most Chinese. But, could the party itself defy this emotion duplex? No, it couldn't. Since political parties are human organizations, none of them can escape the gravitational pull of human emotions. Even in the most chaotic time of its reign, the party had never stopped branding image and building connections in the international arena. As China's economic reform came into fruition, it has become increasingly eager in seeking acceptance and respect from the rest of the world. Yet, among many reasons, it is precisely because of its bloodstained revolution "(in)glory" that Western countries keep turning a deaf ear to its yearning. The party's "soft power push" is unlikely to achieve intended effects in the foreseeable future.

\section{References}

"China Awards Top Ten International Friends". (2009). People.cn. Retrieved from http://en.people.cn/90001/90776/90883/6836045.html

“Epstein’s Body Cremated in Beijing” (“爱泼斯坦遗体在京火化”). (2005). CCTV. com. Retrieved from http://www.cctv.com/news/china/20050603/102688.shtml

“Israel Epstein”. (2005). The Telegraph. Retrieved from http://www.telegraph.co.uk/news/obituaries/1491973/Israel-Epstein.html

“Premier Wen Jiabao visits Senior Foreign Expert Israel Epstein” (“国务院总理温家宝看望外国老专家爱泼斯坦”). (2003). People.cn. Retrieved from http://people.com.cn/GB/shizheng 16/20030420/976253.html

“President $\mathrm{Hu}$ Jintao Visits Israel Epstein” (“胡锦涛亲切看望爱泼斯坦”). (2005). People.cn. Retrieved from http://politics.people.com.cn/GB/1024/3327158.html

“President Jiang Zemin Congratulated Israel Epstein on His 80th Birthday in 1995” (“1995年江泽民祝贺爱泼斯坦80大寿”). (2005). China.com. Retrieved from http://www.china.com.cn/chinese/zhuanti/at/840297.htm

"Revolution". (2015). Encyclopedia Britannica. Retrieved from https://www.britannica.com/topic/revolution-politics

“Zhu Rongji meets Israel Epstein” (“朱镕基接见爱泼斯坦”). (2005). China.com. Retrieved from http://www.china.com.cn/chinese/zhuanti/at/840306.htm

Arendt, H. (2006). On revolution. New York: Penguin Books.

Bennett, A., \& Rittenberg, S. (1993). The man who stayed behind. New York: Simon \& Schuster.

Brady, A. M. (2003). Making the foreign serve China: Managing foreigners in the People's Republic. Lanham: Rowman \& Littlefield Publishers.

Bristow, M. (2011). Sidney Rittenberg: Chairman Mao's favorite American. Retrieved from http://www.bbc.com/news/world-asia-pacific-13974472

Brown, A. (2009). The Rise and Fall of Communism. New York: Harper Collins Publishers.

Chou, D. Y. (2009). Silage Choppers \& Snake Spirits: The Lives \& Struggles of Two Americans in Modern China. Quezon City, Philippines: Ibon Book.

Douglas, M. (2005). Israel Epstein, Prominent Chinese Communist, Dies at 90. Retrieved from http://www.nytimes.com/2005/06/02/world/asia/israel-epstein-prominent-chinese-communist-dies-at-90.html?_r=0

Dutton, M. (2005). Policing Chinese politics: A history. Durham: Duke University Press.

Epstein, I. (2005). My China Eye: Memoirs of a Jew and a Journalist. San Francisco: Long River Press.

Lifton, R. (1989). Thought reform and the psychology of Totalism. Chapel Hill: The University of North Carolina Press.

MAO, Z. D. (1996). Selected works of Mao Tse-Tung (Vol. 2). Peking: Foreign Languages Press.

Meisner, M. (1999). Mao's China and After: A history of the People's Republic (3rd ed.). New York: Free Press.

Robespierre, M. (1987). Report on the principles of political morality (5 February 1794). In K. Baker (Ed.), The Old Regime and the French Revolution. Chicago: The University of Chicago Press.

Selden, M. (1972). The Yenan way in revolutionary China. Cambridge, MA: Harvard University Press.

Shewmaker, K. (1971). Americans and Chinese Communists, 1927-1945. Ithaca, NY: Cornell University Press. 
Spence, J. (1969). To Change China: Western Advisers in China, 1620-1960. Boston: Little Brown.

Vatlin, A., \& Smith, S. (2015). The Comintern. In S. Smith (Ed.), The Oxford Handbook of the History of Communism. Oxford: Oxford University Press.

WU, C. (2013). War journalist Israel Epstein and his dedication to China. Retrieved from http://www.sino-us.com/242/War-journalist-Israel-Epstein-and-his-dedication-to-China.html 